\title{
Modelling human connectome development: precursors to neural circuits
}

\author{
Sreedevi Varier ${ }^{1 *}$, Marcus Kaiser ${ }^{1,2,3}$ \\ From Twentieth Annual Computational Neuroscience Meeting: CNS*2011 \\ Stockholm, Sweden. 23-28 July 2011
}

There are several brain disorders like schizophrenia, autism and certain kinds of epilepsy, which have their origins in early brain development. In vivo studies can be extremely complex and riddled with technical and practical hurdles, heralding the need for in silico models for testing hypotheses. To fully understand brain network diseases, it is essential to find out which developmental factors lead to altered network topologies and resulting functional changes such as waves or large-scale activations (as for epileptic seizures). Recent results on local neuronal development have shown how preferences for short-distance connections [1] as well as how long-distance connections can arise [2].

Here, we present a model that simulates the layered development of the human neocortex, from the division of neural precursors to the establishment of layers and connections. Results from the model focus on the emerging network characteristics of cortical networks as synaptic connections are established. We test how quantitative and qualitative network features relate to changes in developmental factors, such as time-windows, spatial positions and chemical gradients.

Results from the model include identification of developmental factors influential in the formation of cortical networks, highlighting those yielding aberrations. In conclusion, the model might inform future clinical and experimental work on the developmental origins of brain network disorders.

\footnotetext{
Author details

${ }^{1}$ School of Computing Science, Newcastle University, UK. ${ }^{2}$ Institute of Neuroscience, Newcastle University, UK. ${ }^{3}$ Department of Brain and Cognitive Sciences, Seoul National University, Korea.

Published: 18 July 2011

* Correspondence: Sree.Varier@ncl.ac.uk

${ }^{1}$ School of Computing Science, Newcastle University, UK

Full list of author information is available at the end of the article
}

References

1. Kaiser M, Hilgetag CC, van Ooyen A: A simple rule for axon outgrowth and synaptic competition generates realistic connection lengths and filling fractions. Cerebral Cortex 2009, 19(12):3000-3010.

2. Varier S, Kaiser M: Neural development features: Spatio-temporal development of the Caenorhabditis elegans neuronal network. PLOS Comput Biol 2011, 7(1):e1001044.

doi:10.1186/1471-2202-12-S1-P163

Cite this article as: Varier and Kaiser: Modelling human connectome development: precursors to neural circuits. BMC Neuroscience 201112 (Suppl 1):P163.
Submit your next manuscript to BioMed Central and take full advantage of:

- Convenient online submission

- Thorough peer review

- No space constraints or color figure charges

- Immediate publication on acceptance

- Inclusion in PubMed, CAS, Scopus and Google Scholar

- Research which is freely available for redistribution

Submit your manuscript at www.biomedcentral.com/submit
C Biomed Central
C Biomed Central

(c) 2011 Varier and Kaiser; licensee BioMed Central Ltd. This is an open access article distributed under the terms of the Creative Commons Attribution License (http://creativecommons.org/licenses/by/2.0), which permits unrestricted use, distribution, and reproduction in any medium, provided the original work is properly cited. 